\title{
Backlash against DNA ventures?
}

\section{More thoughts at Harvard on business link}

\section{Washington}

Harvard University's announcement that it is considering setting up a company to exploit the results of its recombinant DNA research (Nature 30 October, p.769) has provoked a backlash on university campuses that may lead Harvard to drop the idea. The company is seen by some as a threat to academic freedom.

University administrators have, in general, welcomed the Harvard proposal, particularly since many of them are already discussing similar ideas of their own but have not yet made them public.

Yet at the same universities both scientific and non-scientific faculty members have warned of the dangers of steering basic research towards commercial objectives, suggesting that there are elements in the Harvard proposal which make it qualitatively different from more conventional arrangements for linking university research and its industrial applications.

One group which has taken up the issue is the academic freedom committee of the American Civil Liberties Union (ACLU). The committee has set up a subcommittee to draft a possible policy statement for ACLU to consider on guidelines to cover relationships between universities and industry.

"I do not think that you can divorce the universities from industry, but the contribution that we can make is to set guidelines down for the future, for which we feel both faculty and administrators would be appreciative, as they have been in the past on issues such as military research", Dr Bernard Belush, chairman of the academic freedom committee, said last week.

Other universities considering new ways to profit from their research are going through similar debates to that at Harvard, where more than half the faculty members were reported by the Wall Street Journal to have told Harvard president Derek Bok that they were opposed to the idea.

At Yale University in New Haven, for example, the faculty has asked for a revision of proposals which have been put to it for encouraging greater links with industry, and has expanded the committee looking at these proposals - which might, as at Harvard, include the idea of setting up a research development company - to include more non-scientists, who had been among the critics of the original proposal.

A similar debate is expected at the
University of Michigan at Ann Arbor, where there is a proposal to link up with a local pharmaceutical company, Warner Lambert, to provide training facilities for the company's research personnel.

Dr Charles Overberger, vice-president for research at Ann Arbor, said last week that although there were no firm plans to set up a separate company, talks had been held with a venture capitalist, $\mathrm{Mr}$ Herbert Doan, an ex-chairman of the Dow Chemical Company.

At Stanford University in California, where much of the original recombinan DNA research was carried out, the debate is already at an advanced stage. A proposal similar to Harvard's was made several years ago that the university should become more directly involved as an investor in exploiting its research results, rather than merely offering patent rights.

The proposal was, however, shelved after strong opposition from several faculty members, including Professor Paul Berg of the university medical school's biochemistry department.

Rather than getting directly involved, the department is now setting up an industrial affiliates programme under which companies which sign up will be able to send representatives to one seminar a year on the department's work, to receive one visit a year from a faculty member to discuss the company's research and to send a representative to Stanford to discuss this research with faculty members.

In return, the company will give $\$ 12,000$

\section{Science Research Council comes clean}

The UK Science Research Council (SRC), which could not say (see Nature 13 October) how many research grants were outstanding at the end of the last financial year because of a computer oversight, has now produced reliable figures. According to the revised account, 3,933 grants were current on 31 March 1980, of a total value of $£ 120.5$ million. This is an increase in number of 15 per cent and in value of 34 per cent over the previous year.

The increase is still substantial and unplanned. Indeed, it is the first major increase of grant allocations for many years. It is only partly accounted for by the "equipment round", a $£ 7.5$ million handout for major items of equipment in universities which took place in the summer of 1979 .

Last week the Department of Education and Science (DES) came to SRC's aid, allowing the council to transfer $£ 5.7$ million of its savings on foreign subscriptions, due to the strong pound, to other accounts. SRC can thus pay for some of this year's increased expenditure on grants. Even so, the council was due this week to seek another $£ 2$ million of savings on current spending, on top of $£ 4$ million annually to the university, which the department hopes will be used to support junior research posts. Fifteen companies - including Cetus, Genentech and several major pharmaceutical firms - have already signed up, and the department has a growing waiting list.

Dr Donald Kennedy, who took over as Stanford's president earlier this year after spending four years as head of the Food and Drug Administration in Washington, admits that the new commercial pressures on biological research have thrown up a variety of problems which biomedical researchers have never previously had to face. "Quite possibly it is time for some leadership to be sought or to well up in universities on this point as it has done on other points in the discussion of the social responsibilities of scientists", says Dr Kennedy. "Perhaps it is time for another Asilomar, but it ought to come from the people who are doing the science."

At Harvard, university officials insist that they have gone to considerable lengths to prevent any potential conflict of interests between the academic goals of the institution and its investment policies. For example, no university administrators would be directly involved in investment decisions taken by the new company, which would be completely separate from the university. Although the university would be a minority shareholder, it would not be investing any of its endowment, since the shares would be provided in return for access to research results.

worth of cuts already made.

SRC will therefore scrape through the current financial year without requiring extra finance from DES - but the year to follow (April 1981 to March 1982) looks increasingly bleak. The pound seems unlikely to rise further against the European currencies in which foreign subscriptions are mostly paid, and indeed it may fall if interest rates in London money markets are reduced. Thus the $£ 5.7$ million found on exchange rates this year may vanish or even become negative next year, while the grant commitment will remain obstinately high.

Next year, accordingly, the council will have to seek an increase in its funding above the $£ 175.3$ million included in the provisional 1980 five-year forward look, to pay for its support for the universities last year. There is no reason to suppose that the other dependants of the Advisory Board for the Research Councils will be sympathetic. The council's finances are, however, unlikely to be seriously affected if it is required to refund the price of its annual report (HMSO, £7.50) to purchasers complaining that the figures it contains are wrong.

Robert Walgate 
Whether this will be sufficient to answer the critics remains uncertain. While scientists were voicing their fears about academic freedom, several investment houses were saying in public last week that they thought it was a bad thing for a university to get involved in commercial operations. Dr Bok's announcement about whether the university intends to go ahead with plans to set up the new company is therefore awaited with great interest.

David Dickson

European science

\section{Foundation stones}

\section{Strasbourg}

The European Science Foundation ended its annual general assembly here last week (13 November) in a vaguely hesitant frame of mind. Unlike previous assemblies, this was less a general amplification of the enthusiasm for international collaboration of member organizations (now 47 research councils and learned academies from 18 countries) than a reluctant recognition that the next six years may be more difficult than the past - and first - six.

Part of the hesitancy stems from changes of personnel. Lord Flowers, rector of Imperial College, London, and president of the foundation for the past six years, handed over at this year's assembly to Professor H. Curien, director of the CNRS (Centre National d'Etudes Spatiales) in Paris, while Dr. John Goormaghtigh succeeded Dr Friedrich Schneider as secretary-general only a year ago. But the member organizations seem also to be preoccupied with domestic funding problems and thus less able to think expansively than in recent years.

Several of the foundation's recent initiatives appear also to be at critical, even anxious, stages. Thus the development of a plan for what is called the European Synchrotron Radiation Facility, on which a foundation study group has been working for the past three years, is in the air. At the general assembly in 1979, the retiring secretary-general, Dr Schneider, was asked to spend a year sounding out European governments on their willingness to contribute towards the cost of the machine, estimated at something of the order of $\$ 100$ million.

Dr Schneider appears to have found this a disappointing year. Potential contributors to the cost of the machine have taken the view that haste might jeopardize eventual construction. Some governments also appear to be suspicious that the foundation is usurping their role of making treaties among themselves for multinational projects. The study group (under Professor Y. Farge of Orsay) will, nevertheless, remain in being during 1981, concentrating on the further refinement of its proposals.

The foundation is also despondent about the prospects for space research in Europe. A year ago, one of the foundation's published reports took the European Space Agency to task for the degree to which its then programme was biased to the development of the Ariane launching system, to the detriment of plans for launching scientific satellites. At this assembly, delegates were told that there has been no substantial improvement. Plans for launching European scientific satellites are so sparse that scientists who are members of space research groups in Europe may have to wait about five to seven years between successive experiments. Professor Curien told the assembly that this might be inevitable in studies of "the reproduction of the elephant, or of silviculture", but that it was

\section{Something ventured, something done}

Both the new research projects approved by the 1980 assembly are in the social sciences. One, under the rubric of "comparative law", and to which ten countries have agreed to contribute, includes an attempt to define and compare the medical responsibility within Europe. The study will include the responsibilities of physicians and drug firms towards patients and the influence of medical insurance on the behaviour of physicians. There is also to be a European study of procedures for summary jurisdiction in civil and other courts.

The social scientists are preoccupied with migration and language, and have won approval for two other research projects - the problems of language acquisition by adult migrants within Europe (of whom there are estimated to be 11 million) and a series of research workshops on the human and cultural aspects of migration within Europe.

There is also to be a one-year study of problems of technical innovation and social change, chiefly so as to identify fields in which coordination by the foundation might be beneficial.

Continuing projects that appear to be flourishing, or nearing fruition, include: - Chinese studies. A handbook of Chinese literature in the period $1900-49$ is nearing completion, while a descriptive catalogue of the body of fifteenth century Chinese literature known as the TaoTsang is well under way.

- Brain and behaviour research. The foundation plans to spend in 1981 a total of FF1.3 million on this programme of training awards and travel grants.

- Taxonomy. The ad hoc group on European taxonomy is to be disbanded, and its final report published in March next year. The draft report claims to have made substantial progress towards understanding the difficulties of coordinating European taxonomic nomenclature. an entirely artificial circumstance in space research.

The foundation is not, however, entirely frustrated. Its programme on polymer structure is going well (see box), while the assembly agreed to launch a number of new projects in the social sciences while continuing most of its past successes, the programme of training in "brain and behavioural research", for example.

On more general questions, the foundation has decided to keep in being the Liaison Committee on Recombinant DNA Research even though, according to a statement from the committee, the need for attempts to coordinate containment guidelines has melted away. The focus of anxiety has moved to what are called "second generation" issues, including the pace and the manner in which recombinant DNA techniques are being commercialized with the possible consequential risks to academic research. Dr Philip Handler, president of the US National Academy of Sciences, said in his invited address to the assembly that academics forming commercial links with DNA companies were "creating a great deal of difficulty for the others working in this field".

The foundation has also issued a statement asking that national governments planning new legislation on the confidentiality of computerized data banks should also bear in mind the value of such data, suitably shorn of identification, for the research community.

The assembly approved the foundation's budget for 1981, which exceeds FF5 million for the first time, and which does not include the cost of the special research projects (called "additional activities") to which member organizations contribute on a voluntary basis.

Lord Flowers estimated, in his final address to the assembly, that the total expenditure on the foundation's activities amounted to less than 0.1 per cent of the budgets of member organizations, and hoped that the next six years would see a tenfold increase in this proportion in the next six years, as well as a further extension of the foundation's sphere of interest. The academy of Finland was admitted as a full member of the foundation with effect from 1981.

\section{Fusion research}

\section{Livermore looks up}

\section{Washington}

After a period of considerable uncertainty, scientists in the two main fusion energy programmes at the US Department of Energy's Lawrence Livermore Laboratory in California are confident that recent technical advances are given a significant boost to the chances of being able to exploit nuclear fusion as a commercial source of power.

In the magnetic confinement programme, successful tests with so-called tandem mirrors, which could be used to 